\title{
Cystoid Macular Edema
}

National Cancer Institute

\section{Source}

National Cancer Institute. Cystoid Macular Edema. NCI Thesaurus. Code C34794.

An accumulation of fluid in the outer plexiform layer, secondary to an increase in permeability of perifoveal retinal capillaries. 